\title{
Abnormalities in the male developmental programme of winter wheat induced by climatic stress at meiosis
}

\author{
$\mathrm{S}$ Demotes-Mainard ${ }^{1 *}$, G Doussinault ${ }^{1}$, JM Meynard 2 \\ 1 Station d'amélioration des plantes, Inra, BP 29, F-35650 Le Rheu; \\ 2 Laboratoire d'agronomie, Inra, F-78850 Thiverval-Grignon, France
}

(Received 23 February 1996; accepted10 September 1996)

\begin{abstract}
Summary - From the onset of meiosis, wheat plants, cv Moulin and Pernel, were subjected to climatic stress for 7 days in a growth chamber. The stress conditions $\left(11 \mu \mathrm{mol} \cdot \mathrm{m}^{-2} \cdot \mathrm{s}^{-1}\right.$ photosynthetic photon flux density, $1.5 / 8{ }^{\circ} \mathrm{C}$ night/day, $12.5 \mathrm{~h}$ photoperiod) were chosen so that the stress affected the grain set in a similar way to low radiation, possibly associated with chilling in the field. Control plants received $203 \mu \mathrm{mol} . \mathrm{m}^{-2} \cdot \mathrm{s}^{-1}$ photosynthetic photon flux density, $15 / 18^{\circ} \mathrm{C}$ temperatures and $16 \mathrm{~h}$ photoperiod. In stressed plants, the grain set was reduced due to poor fertilization, as shown by the absence of development of endosperms from the embryo sacs. Male development was affected: anthers were frequently small, curved or shrivelled, and did not dehisce. Pollen release was limited and the pollen load on the stigma was low. Pollen viability (fluorochromatic reaction) was altered, but pollen grains were normally trinuclear at anthesis. Female fertility was unaffected. Both varieties showed the same alterations.
\end{abstract}

sterility / meiosis / low radiation / chilling temperature / Triticum aestivum $\mathrm{L}=$ wheat

Résumé - Anomalies dans le programme mâle du blé d'hiver induites par un stress climatique à la méiose. Du blé (variétés Moulin et Pernel) a été soumis à un stress climatique durant 7 jours à partir du début de la méiose, en chambre de culture. Les conditions de stress (densité de flux de photons de $11 \mu \mathrm{mol} . \mathrm{m}^{-2} . \mathrm{s}^{-1}, 1,5 / 8{ }^{\circ} \mathrm{C}$ nuit/jour, photopériode de $12 \mathrm{~h}$ 30) ont été choisies de façon à ce que ce stress ait les mêmes effets sur la nouaison qu'un éclairement faible, éventuellement accompagné d'une température basse, au champ. Les plantes témoins étaient soumises à une densité de flux de photons de $203 \mu \mathrm{mol} . \mathrm{m}^{-2} . \mathrm{s}^{-1}$, des températures de $15 / 18^{\circ} \mathrm{C}$ et une photopériode de 16 heures. Chez les plantes stressées, la nouaison a été réduite suite à un déficit de fécondation, mis en évidence par l'absence de développement d'albumen dans les sacs embryonnaires. Le développement mâle a été affecté : de nombreuses anthères étaient petites, incurvées ou recroquevillées et non déhiscentes. La libération du pollen a été réduite et la quantité de pollen disséminée sur les stigmates était faible. La viabilité du pollen (réaction fluorochromatique) a été altérée, en revanche les grains de pollen étaient normalement trinucléés lors de l'anthèse. La fertilité femelle n'a pas été affectée. Les deux variétés ont présenté les mêmes altérations.

stérilité / méiose / éclairement faible / température basse / Triticum aestivum $L=$ blé

* Correspondence and reprints: Laboratoire d'agronomie, Inra, F-78850 Thiverval-Grignon, France. 


\section{INTRODUCTION}

In wheat, as in many other species, meiosis is a stage that is particularly sensitive to climatic stresses, such as heat stress (Saini and Aspinall, 1982), water deficit (Saini and Aspinall, 1981), low radiation (Demotes-Mainard et al, 1995) and subzero temperatures (Kim et al, 1985). These stresses can result in large losses in kernel number per spike. Kernel number is highly correlated with yield in wheat, and so the study of these phenomena is of economic interest. High temperatures and water deficit at meiosis reduce the grain set by inducing male sterility and also, in the case of heat stress, female sterility. The components of the male and female developmental programmes altered by these stresses, as well as the nature of the injury have been described (Saini and Aspinall, 1981; Saini et al, 1983, 1984). When kernel number is reduced due to low radiation at meiosis, pollen viability is altered independently of the presence of chilling (DemotesMainard et al, 1995). However, the responses of the other components of male fertility have not been characterized, and the response of female fertility remains unknown. We therefore investigated the plant components altered and the nature of the infertility, following a stress at meiosis causing a drop in kernel number. The stress chosen aims at inducing similar effects to those observed in the field when radiation is low at meiosis.

\section{MATERIALS AND METHODS}

\section{Plant materials and culture}

Two varieties of winter wheat (Triticum aestivum $\mathrm{L}$ ), Moulin and Pernel, were chosen for their sensitivity to low radiation at meiosis (Demotes-Mainard et al, 1995). Plants were grown in individual pots filled with soil. After vernalization, plants of the variety Moulin were transferred to growth chamber No 1 (203 $\mu \mathrm{mol} . \mathrm{m}^{-2} . \mathrm{s}^{-1}$ photosynthetic photon flux density (PPFD), $15 / 18^{\circ} \mathrm{C}$ night/day temperatures and $16 \mathrm{~h}$ photoperiod), and the variety Pernel remained outdoors until meiosis. Meiosis, which is synchronous in the microsporocytes and in the megasporocyte within a floret (Bennett et al, 1973), was assessed nondestructively in the spike of each main shoot, using the method described by Demotes-Mainard et al (1995).

\section{Experimental treatments}

At the onset of meiosis, plants were placed in two different growth chambers and subjected to the two fol- lowing experimental treatments for 7 days: control: $203 \pm 26 \mu \mathrm{mol} . \mathrm{m}^{-2} . \mathrm{s}^{-1} \mathrm{PPFD}, 15 / 18^{\circ} \mathrm{C}$ night/day temperatures, $16 \mathrm{~h}$ photoperiod (growth chamber No 1); stress: $11 \pm 1 \mu \mathrm{mol} . \mathrm{m}^{-2} . \mathrm{s}^{-1}$ PPFD, $1.5 / 8{ }^{\circ} \mathrm{C}$ night/day temperatures, $12.5 \mathrm{~h}$ photoperiod (growth chamber No 2).

Radiation was provided by high pressure sodium lamps (growth chamber No 1) or by fluorescent lamps (growth chamber No 2). Plant assignment to either of the treatments and position in the growth chambers were fully randomized. After 7 days, all stressed plants were placed in growth chamber No 1 beside the control plants, until kernel number was established (post anthesis).

The levels of radiation and temperature were chosen so that the stress was severe, in order to be able to identify components of fertility that were unaffected. The difference in photoperiod and type of lamps between the control and stress treatments was due to material constraints. However, previous experiments (Demotes-Mainard et al, 1996) showed that these stress conditions have similar effects as a climatic accident involving low radiation and possibly chilling on grain set of a field grown crop (same pattern of grain set and same drop in grain number).

\section{Observations}

\section{Cv Moulin}

The frequency of fertilization was estimated as the percentage of embryo sacs that had developed and endosperm 4.5 days after pollination. About 100 ovaries per treatment were examined as described by Sitch and Snape (1987). These ovaries had been previously hand-pollinated with the anthers of their own floret.

The level of female fertility was assessed by artificial pollination. Thirty ears of control plants and 30 ears of stressed plants were emasculated 1 day before flowering. They were pollinated with the pollen of three control ears that were enclosed in a cellophane bag with each emasculated ear. Grain set was recorded as the percentage of florets that had developed a grain.

Male fertility was determined by observing anther morphology, dehiscence, pollen dissemination, pollen viability and number of nuclei per pollen grain at anthesis. Anther morphology was considered normal if an anther was green or yellow-green, had swollen anther bags and normal size and shape 1 or 2 days before anthesis. The anthers of 750 florets per treatment were examined. To record anther dehiscence and pollen dissemination, stamens and pistils were sampled on the day when anthers of each floret became dehiscent. Therefore, the ears were observed on a daily basis to determine the progression of anthesis between florets. The floral organs were fixed and then stained in acetocarmine. The number of dehiscent loculi per anther was recorded. The pollen grains remaining in an anther after dehiscence tend to be packed at the base 
of the anther loculi. Pollen dissemination was therefore estimated as the percentage of the volume of the anther bags that was empty of pollen grains. Pollen load on the stigmas was estimated by counting the number of pollen grains per pistil. Floral organs of 130 florets per treatment were examined. Pollen viability was tested using the fluorochromatic reaction (FCR) test (Heslop-Harrison and Heslop-Harrison, 1970). Fifty anthers per treatment were sampled just before dehiscence and the percentage of pollen viability was measured using a sample of 400 pollen grains per anther. The number of nuclei per pollen grain was counted at anthesis on 25 anthers per treatment and 400 pollen grains per anther, employing DAPI (4',6diamidino-2-phenylindole) fluorochrome (Vergne et al, 1987). The plants used for the observations with DAPI were grown under the same conditions as the other plants but in an independent experiment.

All the observations were performed on the main shoot and on the first tiller of each plant. Within a spikelet, only the first and second florets that were judged to be fully developed, and therefore potentially fertile, were considered. Artificial pollinations and observations of anther morphology involved spikelets of the whole ear, whereas only the spikelets of the middle region of the ear were used for the other observations. The experimental design included total randomization; in the analyses of variance, the rank of the tiller and the experimental treatment were considered as fixed factors.

Table I. Variance analysis: effect of a climatic stress at meiosis on grain set in self-pollination in the cv Pernel.

$\begin{array}{lcll}\text { Sources of variation } & \mathrm{df} & \text { Sum of squares } & \mathrm{Pr}>\mathrm{F} \\ \text { Treatment } & 1 & 1.088 & 0.0001 \\ \text { Tiller rank } & 1 & 5.661 \times 10^{-3} & 0.425 \\ \text { Treatment } \mathrm{x} \text { tiller } & 1 & 3.465 \times 10^{-2} & 0.051 \\ \text { Residual } & 64 & 0.5621 & \end{array}$

\section{Cv Pernel}

Grain set was determined as the percentage of the first and second florets of each spikelet that had developed a kernel at maturity. To prevent cross-pollination, the ears were bagged before flowering. Grain set was measured on about 30 ears per treatment.

The artificial pollination technique to study female fertility and methods used to record data on anther morphology, dehiscence and pollen dispersal were the same as those used for cv Moulin. Pollen viability and number of nuclei per pollen grain were not examined. For each treatment, 25 ears were used for artificial pollination, stamens of 700 florets were used to determine anther morphology and those of 90 florets for anther dehiscence and pollen dissemination.

Only the first and second florets of a spikelet were sampled on the ears of the main shoot and of the first tiller. The spikelets of the whole ear were used for observations, except those of anther morphology for which only the six spikelets located at the top and the six spikelets located at the base of the ear were used. The experimental design was the same as for $\mathrm{cv}$ Moulin.

\section{RESULTS}

The percentage of embryo sacs of Moulin that had developed an endosperm 4.5 days after pollination was significantly lower $(P<0.01$ level, Chi-square test) for the stressed plants $(24.0 \%)$ than the control plants $(81.9 \%)$. The treatment had no effect on the aspect of endosperm cells.

The percentage of grain set obtained by selfpollination in Pernel was significantly different $(P<0.01$, analysis of variance, table $\mathrm{I})$ in control plants $(93.5 \%)$ and in stressed plants $(68.2 \%)$.

Grain set obtained by artificial pollination between control pollen and either control emasculated ears or stressed emasculated ears was not significantly different within each variety at $\mathrm{P}<0.05$ (analysis of variance, table II). In

Table II. Variance analysis: effect of a climatic stress applied to the female alone on grain set in artificial pollination.

Source of variation

\begin{tabular}{|c|c|c|c|c|}
\hline & & df & Sum of squares & $\operatorname{Pr}>F$ \\
\hline 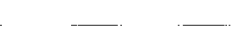 & - & & $\cdots$ & - \\
\hline eatment & & 1 & $1.945 \times 10^{-3}$ & 0.325 \\
\hline Tiller rank & & 1 & $6.009 \times 10^{-3}$ & 0.086 \\
\hline Treatment $\mathrm{x}$ tiller & & 1 & $1.546 \times 10^{-2}$ & 0.0070 \\
\hline Residual & & 56 & 0.1103 & \\
\hline
\end{tabular}

Cv Pernel

\begin{tabular}{|c|c|c|}
\hline df & Sum of squares & $\mathrm{Pr}>\mathrm{F}$ \\
\hline & - & $\ldots$ \\
\hline 1 & $2.235 \times 10^{-4}$ & 0.88 \\
\hline 1 & $1.139 \times 10^{-2}$ & 0.29 \\
\hline 1 & $9.894 \times 10^{-4}$ & 0.75 \\
\hline 42 & 0.4112 & \\
\hline
\end{tabular}



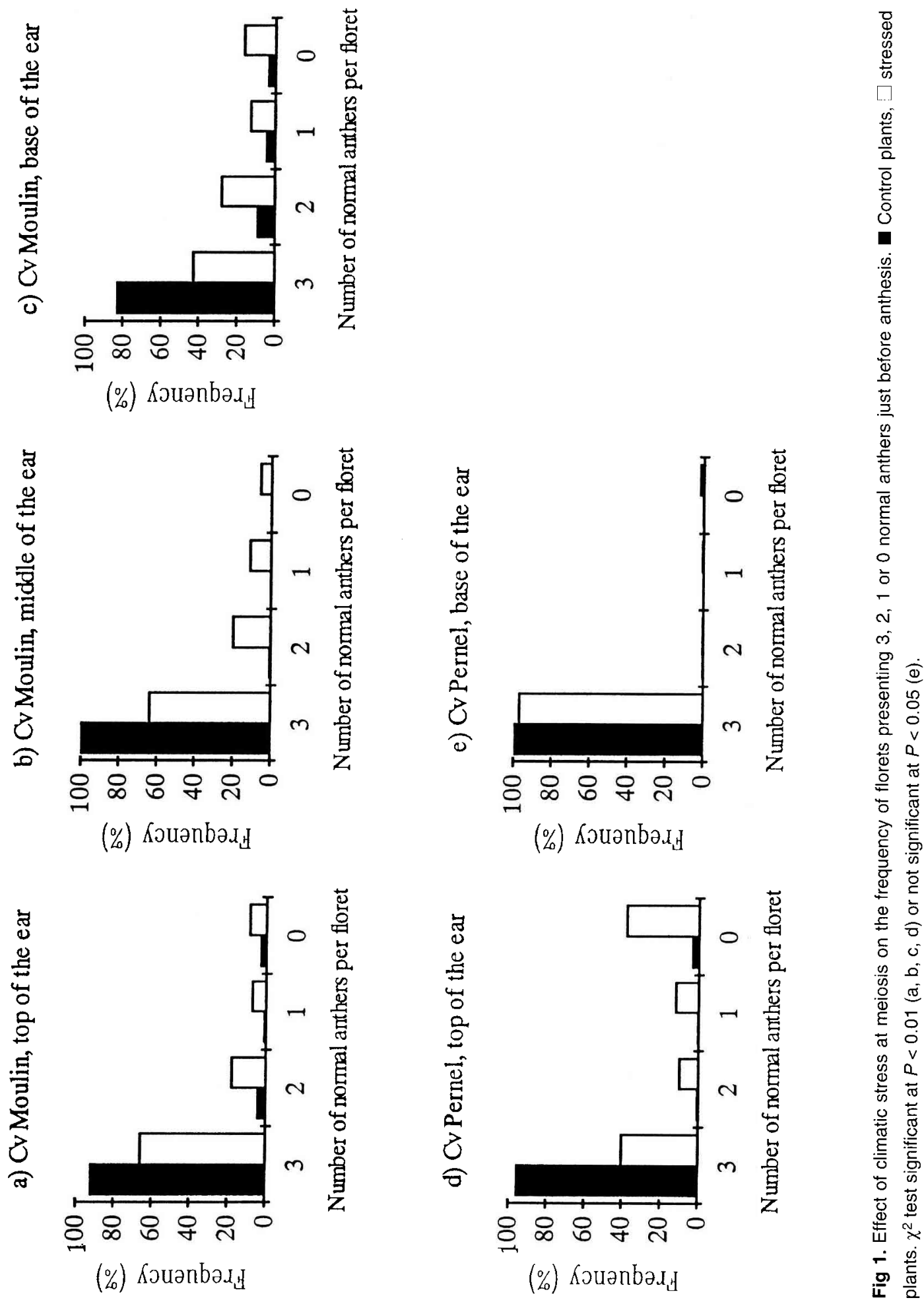

(\%) Кэuәпьวан

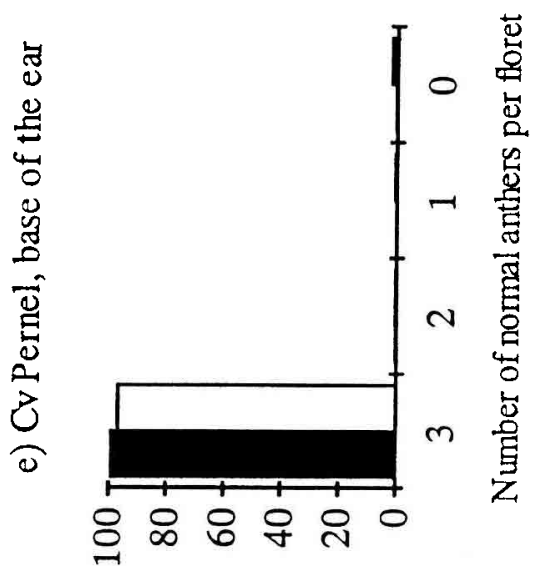

(\%) Коuวnbว.

(\%) Кวuәnbว.

高高 
Moulin, grain set was $91.4 \%$ in the cross between control emasculated ears and control pollen versus $91.9 \%$ in the cross between stressed emasculated ears and control pollen. In Pernel, $90.9 \%$ of the florets developed a grain in the cross with control females and $91.5 \%$ with stressed females.

For the two varieties tested, and in all positions of the spikelets in the ear (fig 1), nearly all the anthers of plants subjected to the control treatment had a normal morphology. Plants subjected to the stress at meiosis contained abnormal anthers: they were small, curved, shrivelled or X-shaped, frequently white or sometimes precociously yellow. In Moulin, the number of florets containing three normal anthers was lower in stressed plants than in control plants for all positions of the spikelets in the ear (difference between treatments: $25.9-40.2 \%$ according to the part of the ear). In Pernel, the stress decreased $(-55.7 \%)$ the frequency of florets containing three normal anthers in the upper spikelets, the reduction being associated with an increase $(+34.7 \%)$ in the percentage of florets with three damaged anthers. No significant difference between control and stressed plants was observed at the basal part of the ear.

Anther dehiscence, studied only on anthers presenting a normal morphology, was affected by climatic stress at meiosis (fig 2). In Moulin, the frequency of anthers with four dehiscent loculi was lower $(-20.2 \%)$ in stressed than in control plants, due to an increase in the proportion of indehiscent anthers. In Pernel, the stress increased the frequency of anthers with no or two dehiscent loculi at anthesis in the upper part of the ear $(+18.2 \%)$ and in the middle part of the ear $(+17.2 \%)$. The treatments had no effect on the basal spikelets of Pernel.

Only anthers presenting a normal morphology were used to study pollen dissemination. To measure the pollen release per floret, a mean value of pollen absent from the three stamens of each floret was obtained. In Moulin, the percentage of pollen released per floret in median spikelets was lower in stressed than control plants (fig 3). In Pernel, the proportion of pollen released per floret from the upper spikelets was reduced by the stress but median and basal spikelets were unaffected. However, in both varieties tested, the stress-associated reductions were not significant when only florets with three dehiscent anthers were considered.
In Moulin, stress at meiosis increased the frequency of florets with a very low pollen load on the stigma (fig 4).

Moulin pollen viability was assessed at anthesis by the fluorochromatic reaction. Pollen of damaged anthers was not viable (non-fluorecent). In normal anthers, three types of pollen grains were found; 1 ) fluorescent pollen grains without a vacuole $\left(\mathrm{FCR}^{+}\right)$; 2) fluorescent pollen

a) Cv Moulin, middle of the spike

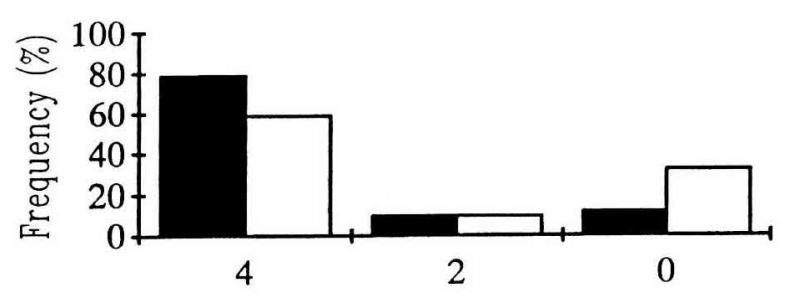

b) Cv Pernel, top of the spike

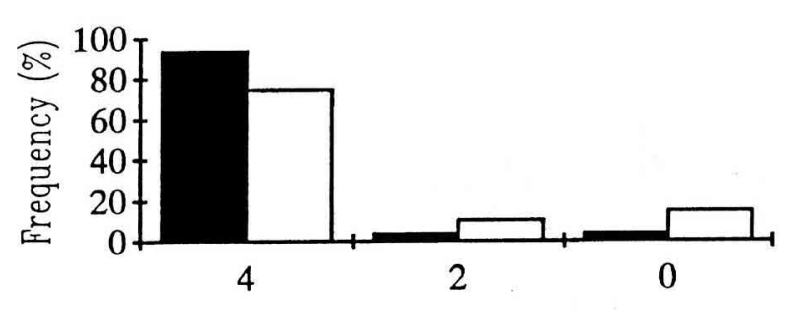

c) Cv Pernel, middle of the spike

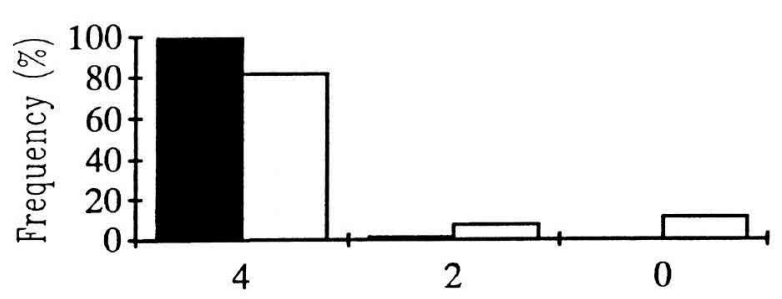

d) Cv Pernel, base of the spike

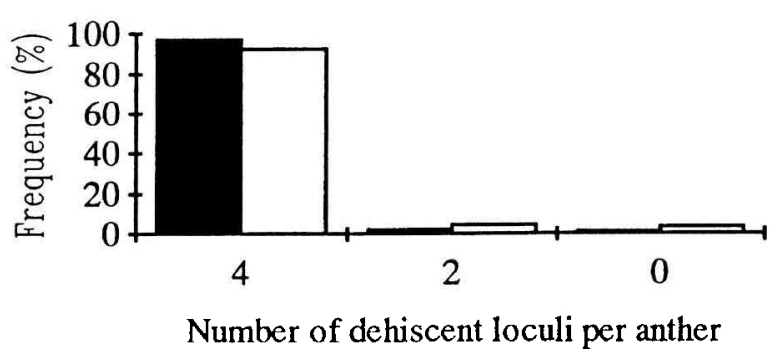

Fig 2. Effect of climatic stress at meiosis on the frequency of anthers having 4,2 or 0 dehiscent loculi at anthesis. Control plants, $\square$ stressed plants. $\chi^{2}$ test significant at $P<$ 0.01 (a, b, c) or not significant at $P<0.05$ (d). 
grains with one big or sometimes several small vacuoles (FCR ${ }^{\text {vac }}$ ): except for the vacuole these pollen grains were similar to $\mathrm{FCR}^{+}$pollen grains (same intensity of fluorescence, same shape); and 3) non-fluorescent pollen grains $\left(\mathrm{FCR}^{-}\right)$. Stress at meiosis significantly reduced the proportion of $\mathrm{FCR}^{+}$pollen grains, which are the normal type observed at anthesis (table III). This reduction was associated with a small increase in

a) Cv Moulin, middle of the spike

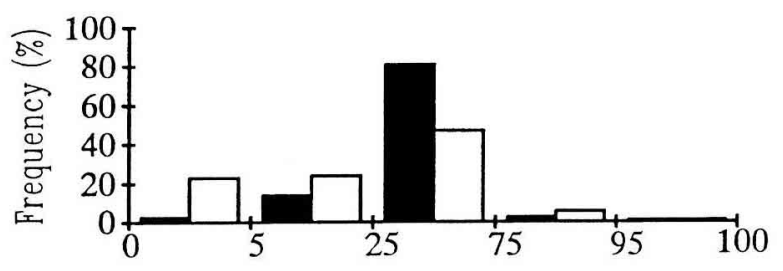

b) Cv Pernel, top of the spike

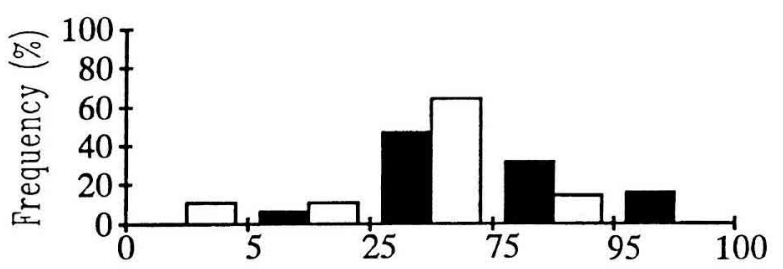

c) Cv Pernel, middle of the spike

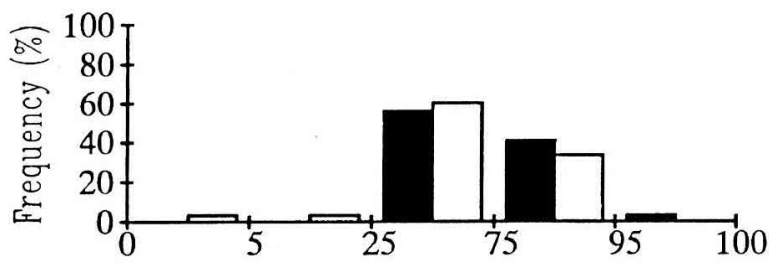

d) Cv Pernel, base of the spike

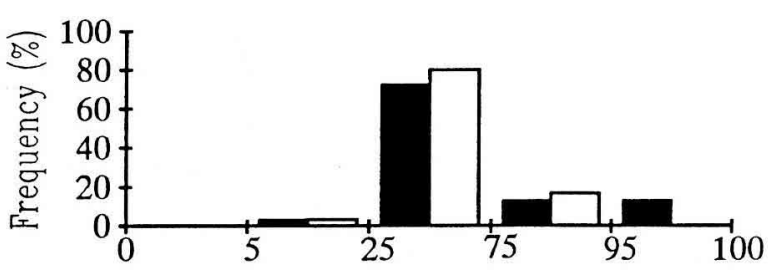

Proportion of released pollen (\%)

Fig 3. Effect of climatic stress at meiosis on the amount of pollen released by the anthers at anthesis. The data correspond to mean values for the three anthers in each floret. $\square$ Control plants, $\square$ stressed plants. $\chi^{2}$ test significant at $P<0.01$ level (a); significant at $P<0.05$ (b); not significant at $P<0.05$ (c, d). the amount of $\mathrm{FCR}^{-}$pollen and a large increase in the amount of FCR ${ }^{\text {vac }}$ pollen (fig 5).

The frequency of trinuclear pollen grains per Moulin anther at anthesis was unaffected by the stress at meiosis $(95.4$ and $94.1 \%$ for the control and the stress treatments respectively) (table IV). Pollen prepared as for the FCR test was gently squashed, for about ten anthers per treatment. In both treatments, fluorescent sperm cells were released, suggesting that the pollen grains were not only trinuclear but also three-celled (data not shown). In a large majority of pollen grains, contrary to the vegetative nucleus which displayed a rounded shape, the sperm nuclei displayed an elongated shape and their chromatin was condensed; no difference was observed between the two treatments (fig 6). The frequency of pollen grains presenting sperm nuclei with a rounded shape was estimated as approximately $1 \%$ of the trinuclear pollen grains. It seemed that this percentage did not increase in stressed plants; however, this comparison relies on an estimation and no statistical analysis was performed.

\section{DISCUSSION}

As for grain sorghum (for review see Salgarolo, 1986), applying a climatic stress to wheat at meiosis decreased grain set by inducing male sterility. Anther morphology was affected and florets could not set grains because damaged anthers contained non-viable pollen grains. These alterations can be particularly important when anther abnormalities involve all three stamens within a floret, as observed in Pernel.

Stress applied at meiosis reduced pollen dispersal from apparently normal anthers. This resulted from anther indehiscence but not from poor pollen release from dehiscent anthers. The

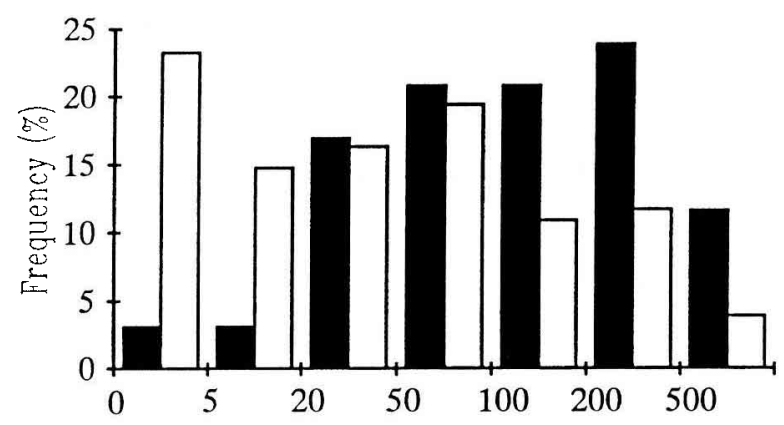

Number of pollen grains per stigma of a floret

Fig 4. Effect of climatic stress at meiosis on the pollen load on the stigma of each floret of Moulin at anthesis. Control plants, $\square$ stressed plants. $\chi^{2}$ test significant at $P<0.01$ level. 
Table III. Effect of a climatic stress at meiosis on the viability of Moulin pollen grains at anthesis, assessed by the FCR test.

A

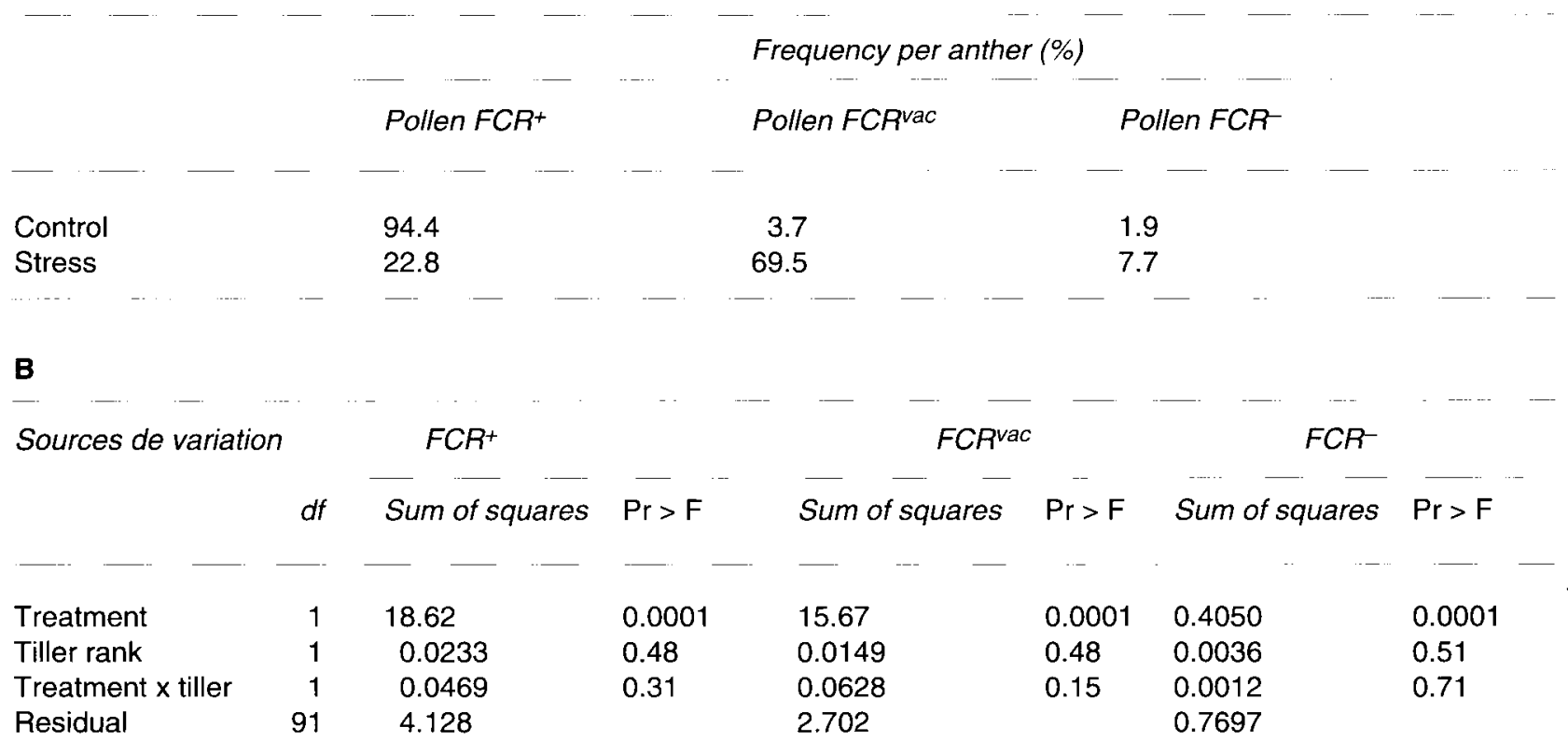

Variance analysis: the angular transformation (Arcsine $\sqrt{x}$ ) was used to fulfil the conditions of normality and homogeneity of the residuals.

numbers of pollen grains per stigma recorded in the control plants are consistent with those observed by Gorin (1950) and Perunova (1954) (both references cited by Rajki and Rajki, 1966). Therefore, these results confirm the fact that our culture conditions did not limit the release of pollen within the floret. The reduction of the pollen load induced by the stress treatment may limit grain set, since the percentage of florets setting a grain depends on the number of pollen grains present on the stigma (Rajki, 1962).

Table IV. Variance analysis: effect of a climatic stress at meiosis on the proportion of pollen grains per anther having three nuclei at anthesis in cv Moulin.

Sources of variation df Sum of squares $\mathrm{Pr}>\mathrm{F}$

$\begin{array}{lrll}\text { Treatment } & 1 & 11.69 \times 10^{-3} & 0.065 \\ \text { Tiller rank } & 1 & 1.13 \times 10^{-3} & 0.56 \\ \text { Treatment x tiller } & 1 & 1.23 \times 10^{-3} & 0.54 \\ \text { Residual } & 50 & 0.164 & \end{array}$

Variance analysis: the angular transformation (Arcsine $\sqrt{ } x$ ) was used to fulfil the conditions of normality and homogeneity of the residuals.
Climatic stress at meiosis affected pollen viability as evidenced by the increase in the proportion of pollen grains reacting negatively to an FCR test (non-fluorescent pollen grains) at anthesis. However, the most frequent alteration consisted of fluorescent pollen grains displaying vacuoles at anthesis. No other test of pollen viability was carried out to check the cellular viability of this vacuolated pollen. A similar response to the FCR test has previously been reported for both cv Moulin and Pernel subjected to low radiation alone (Demotes-Mainard et al, 1995). Both mitoses of the pollen grains were normal, at least as evidenced by the number of nuclei per pollen grain at anthesis.

Climatic stress at meiosis strongly reduced the percentage of embryo sacs developing an endosperm 4.5 days after pollination. Armstrong et al (1987) observed that at this stage, the endosperm of a caryopsis that is about to abort presents different abnormalities or degenerating cells. In our experiment, all the endosperms that were present were normal. Thus, low grain set induced by the stress resulted from an absence of kernel development and not from early caryopsis abortion.

The alterations we observed in the male programme due to the climatic stress at meiosis 

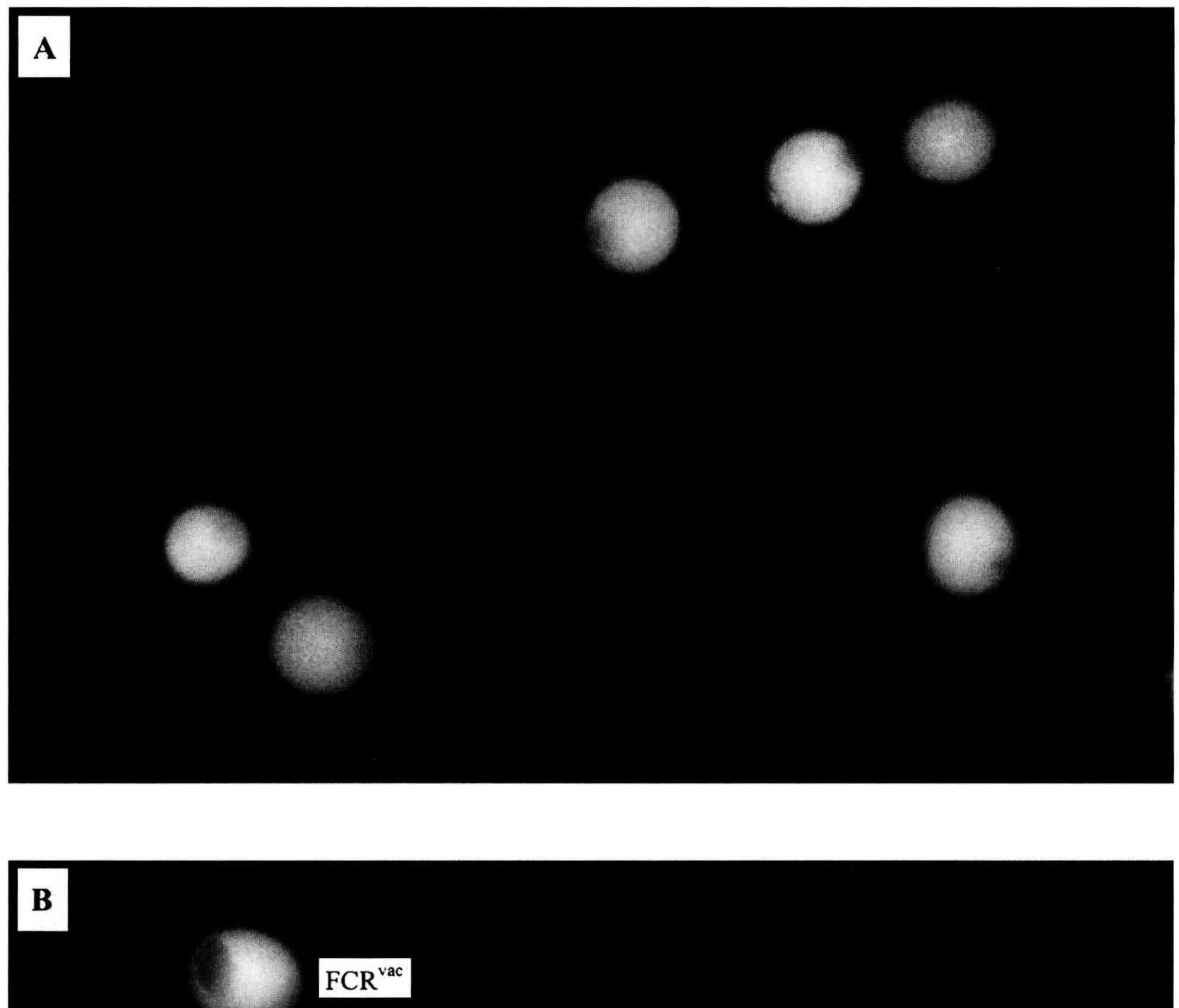

$\mathrm{FCR}^{\text {vac }}$

$\mathrm{FCR}^{+}$

\section{$\mathrm{FCR}^{\mathrm{vac}}$}

Fig 5. Viability assessment of pollen grains at anthesis with the FCR test $(\times 300)$. (A) Representative population of pollen grains from control plants: all gametophytes fluoresce intensely and show no vacuole $\left(\mathrm{FCR}^{+}\right)$. (B) Representative population of pollen grains from stressed plants: the proportion of $\mathrm{FCR}^{+}$pollen grains is reduced, some pollen grains do not fluoresce $\left(\mathrm{FCR}^{-}\right)$, and the majority of pollen grains fluoresce and display a large vacuole $\left(F \mathrm{CR}^{\mathrm{vac}}\right)$. 

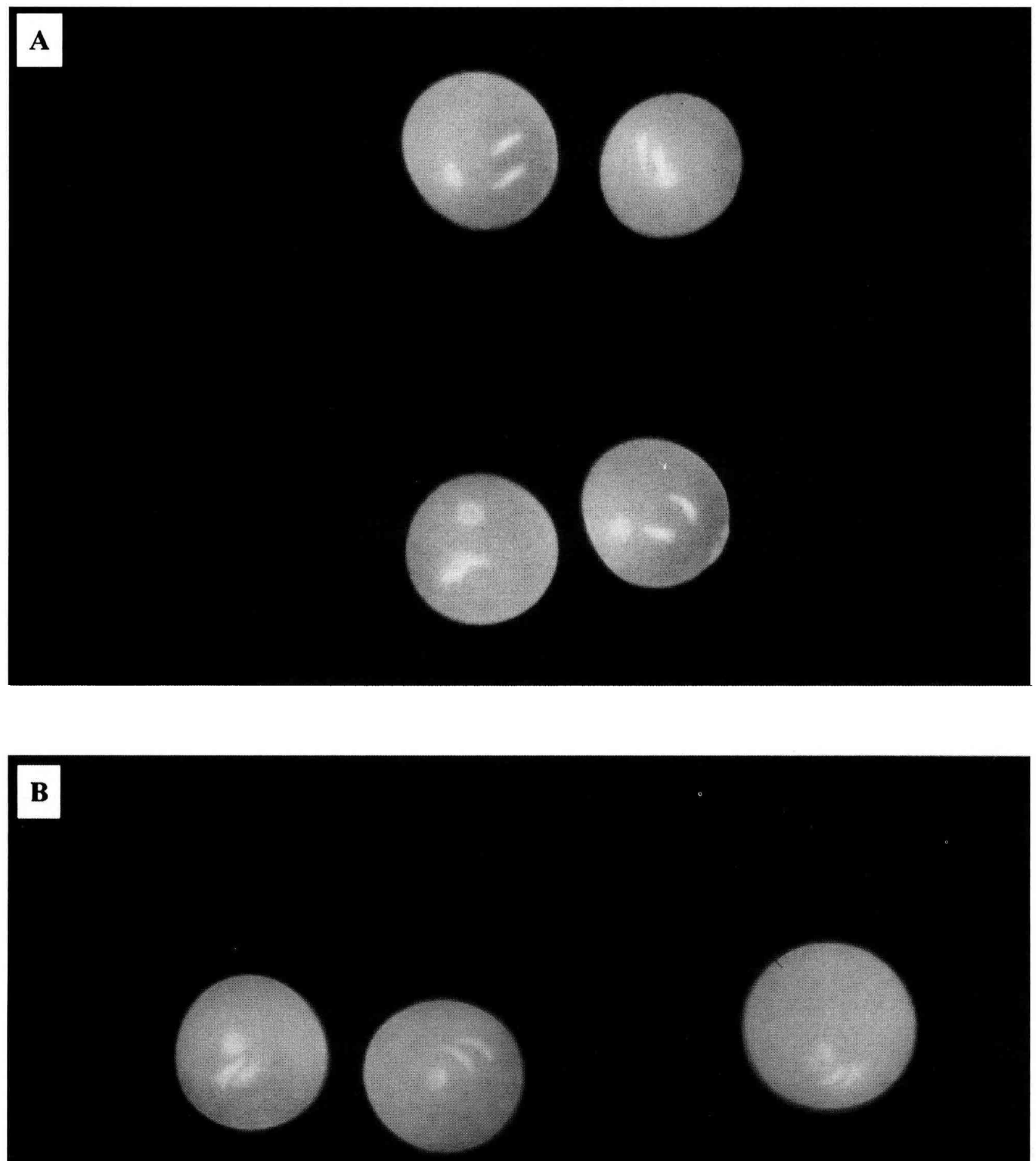

Fig 6. Pollen nuclei visualization by DAPI staining at anthesis (x 535). (A) Pollen grains from control plants. (B) Pollen grains from stressed plants. 
were similar to those observed in various other species in response to different climatic stresses at meiosis. Anther morphology, pollen dispersal and viability in rice (Satake, 1991; Satake and Shibata, 1992), sorghum (Downes and Marshall, 1971; Brooking, 1976, 1979) and mango (Issarakraisila and Considine, 1994) are affected by chilling. Darkness causes pollen sterility in sorghum (Alami et al, 1988). As in our experiment, pollen development stops in the vacuolated pollen stage in sorghum stressed at meiosis by chilling (Brooking, 1976) or darkness (Alami et al, 1988). However, other types of pollen grain alterations have also been recorded, including pollen devoid of normal cytoplasmic constituents (water stressed wheat, Saini and Aspinall, 1981). Other stresses can induce nuclear abnormalities in the pollen grain, contrary to the stress studied in our experiment, such as supernumerary nuclei (sorghum subjected to chilling and darkness at meiosis, Alami et al, 1988) or an arrest of nuclear development at different meiotic stages (wheat grown at chilling temperature during the entire cycle; Qian et al, 1986).

Grain set in the control artificial-crosses (control female $x$ control pollen) was high, of a similar level to grain set following self-pollination (Pernel) or to the rate of embryo sacs that had developed an endosperm (Moulin). This shows that the technique of artificial pollination did not affect grain set. Thus, the absence of difference in grain set between plants that were artificially pollinated with a control or a stressed female shows that female fertility was not affected by climatic stress at meiosis. There are several other reports of female fertility being unaffected by a climatic stress at meiosis that induced male sterility. Examples include sorghum (Downes and Marshall, 1971; Brooking, 1976) and rice (Hayase et al, 1969) responses to chilling and wheat (Saini and Aspinall, 1981) response to water deficit.

The two varieties tested were chosen on the basis of both field observations and control experiments indicating that they are sensitive to low radiation, with or without chilling, at meiosis, and that $\mathrm{cr}$ Moulin was more sensitive than $\mathrm{cv}$ Pernel (Gate, 1995; Demotes-Mainard et al, 1995). We showed that the stress at meiosis resulted in very similar developmental abnormalities in both varieties, the plant components that were affected and the nature of the injury being the same. Thus, the differences observed in various situations between the two varieties in their response to a climatic accident at meiosis involving low radiation were due to a difference of sen- sitivity. The influence of the genotype should be further studied since field observations suggest that some cultivars may not be sensitive to low radiation at meiosis.

\section{ACKNOWLEDGMENTS}

We are grateful to $\mathrm{J}$ Jahier for his advice and to $L \mathrm{Le}$ Rossignol and $\mathrm{E}$ Jaillot for their technical assistance.

\section{REFERENCES}

Alami S, Souvré A, Albertini L (1988) Effets de l'obscurité et du froid sur l'onthogenèse et la viabilité du pollen chez deux variétés de sorgho-grain (Sorghum bicolor (L) Moench). Incidences sur les correspondances entre le développement végétatif, la taille des anthères, et la formation du pollen. Rev Cytol Biol Végét Bot 11, 13-41

Armstrong TA, Soong TS, Hinchee MAW (1987) Culture of detached spikes and the early development of the fourth floret caryopsis in wheat. J Plant Physiol 131, 305-314

Bennett MD, Finch RA, Smith JB, Rao MK (1973) The time and duration of female meiosis in wheat, rye and barley. Proc $R$ Soc Lond B 183, 301-319

Brooking IR (1976) Male sterility in Sorghum bicolor (L) Moench induced by low night temperature. I. Timing of the stage of sensitivity. Aust J Plant Physiol 3, 589-596

Brooking IR (1979) Male sterility in Sorghum bicolor (L) Moench induced by low night temperature. II. Genotypic differences in sensitivity. Aust J Plant Physiol 6, 143-147

Demotes-Mainard S, Doussinault G, Meynard JM (1995) Effect of low radiation and low temperature at meiosis on pollen viability and grain set in wheat. agronomie 15, 357-365

Demotes-Mainard S, Doussinault G, Meynard JM, Gate $P(1996)$ Is it possible to diagnose at harvest a problem of pollen sterility in wheat? Eur J Agron (in press)

Downes RW, Marshall DR (1971) Low temperature induced male sterility in Sorghum bicolor. Aust $J$ Exp Agri \& Anim Husb 11, 352-356

Gate P (1995) Écophysiologie du blé. Lavoisier, Paris

Gorin AP (1950) Biologia tsvetienia i estestvennaia gibridizatsia ou pchenitsi. Dokt Viss TCXA, Moskva (cited by Rajki and Rajki (1966))

Hayase H, Satake T, Nishiyama I, Ito N (1969) Male sterility caused by cooling treatment at the meiotic stage in rice plants. II. The most sensitive stage to cooling and the fertilizing ability of pistils. Proc Crop Sci Soc Jpn 38, 706-711

Heslop-Harrison J, Heslop-Harrison $Y(1970)$ Evaluation of pollen viability by induced fluores- 
cence; intracellular hydrolysis of fluorescein diacetate. Stain Technol 45, 115-120

Issarakraisila M, Considine JA (1994) Effects of temperature on pollen viability in Mango cV 'Kensington'. Ann Bot 73, 231-240

Kim SD, Park ME, Ha YM, Kwon YW (1985) Effect of low temperature on floral sterility, pollen viability and grain yield in barley and wheat. Res Rept RDA (Crops) 27, 114-119

Perunova TV (1954) Biologitcheskie asobennosti apladotvorenia pchenietsi pri miej sartovekh skretsevaniakh. Avtoreferat kand, Diss Odessa (cited in Rajki and Rajki, 1966)

Qian CM, Xu A, Liang GH (1986) Effects of low temperatures and genotypes on pollen development in wheat. Crop Sci 26, 43-46

Rajki E (1962) Effect on pollination of the amount of pollen on the surface of stigma. Növénytermelés 11 , 35-44

Rajki E, Rajki S (1966) Research work on hybrid wheat at Martonvasar. Acta Agron Acad Sci Hung 15, 199214

Saini HS, Aspinall D (1981) Effect of water deficit on sporogenesis in wheat (Triticum aestivum $\mathrm{L}$ ). Ann Bot 48, 623-633

Saini HS, Aspinall D (1982) Sterility in wheat (Triticum aestivum $\mathrm{L}$ ) induced by water deficit or high temperature: possible mediation by abscisic acid. Aust $J$ Plant Physiol 9, 529-537
Saini HS, Sedgley M, Aspinall D (1983) Effect of heat stress during floral development on pollen tube growth and ovary anatomy in wheat (Triticum aestivum L). Aust J Plant Physiol 10, 137-144

Saini HS, Sedgley M, Aspinall D (1984) Developmental anatomy in wheat of male sterility induced by heat stress, water deficit or abscisic acid. Aust $J$ Plant Physiol 11, 243-253

Salgarolo P (1986) Étude des stérilités physiologiques chez le sorgho et de l'effet inducteur des abaissements nocturnes de la température. Thèse de doctorat, INP Toulouse $162 \mathrm{pp}$

Satake T (1991) Male sterility caused by cooling treatment at the young microspore stage in rice plants. XXX. Relation between fertilization and the number of engorged pollen grains among spikelets cooled at different pollen developmental stages. Jpn J Crop Sci $60,523-528$

Satake T, Shibata M (1992) Male sterility caused by cooling treatment at the young microspore stage in rice plants. XXXI. Four components participating in fertilization. Jpn J Crop Sci 61, 454-462

Sitch LA, Snape JW (1987) Factors affecting haploid production in wheat using the Hordeum bulbosum system. I. Genotypic and environmental effects on pollen grain germination, pollen tube growth and the frequency of fertilization. Euphytica 36, 483-496

Vergne P, Delvallée I, Dumas C (1987) Rapid assessment of microspore and pollen development stage in wheat and maize using DAPI and membrane permeabilization. Stain Technol 62, 299-304 